\title{
Incidence of Glucose-6-phoshate Dehydrogenase Deficiency and Correlation with Some Other Laboratory Findings among the Tibetan Refugees in Orissa
}

\author{
Srisha Patel \\ Department of Anthropology \\ B. J.B. College, Bhubaneswar-6, Orissa, India
}

\section{INTRODUCTION}

Deficiency of red cell glucose-6-phosphate dehydrogenase (G-6-PD.) is a genetically determined condition and has been responsible for drug-induced hemolytic anaemia in humans (BEUTLER, 1957). Such defect is present in considerable and varying frequencies in different regions (CHATTERJEA, 1966).

Wide variations in the incidence of the deficiency of G-6-PD. and sickle cell trait have been noted to occur in several populations at different parts of the world. Some attention has also been attracted by the possibility of these two traits influencing each other (LEWIS and HATHORN, 1965).

The purpose of this paper is to bring out up to data on the frequency distribution of such traits among the Tibetan refugees, since there is lacuna of various enzymatic deficiencies among them.

\section{MATERIAL AND METHODS}

The present survey was carried out among the Tibetan refugees at Chandragiri, Ganjam Dist., Orissa. The laboratory findings were correlated with age, sex, sickling and amount of haemoglobin also. Following laboratory investigations were done:-

I). G-6-PD. by Capillary Method (KHER et al., 1967).

II). Sickling by using $2 \%$ sodium metabisulphite as reducing agent (WINTROBE, 1967).
III). Haemoglobin in gram \%(SAHALIS method).

\section{FINDINGS}

Table 1. Incidence of G-6-PD. deficiency in different sexes.

\begin{tabular}{lccc}
\hline Sex & No. of Cases & Positive Cases & Percentage \\
\hline Male & 166 & 6 & 3.6 \\
Female & 133 & 3 & 2.2 \\
Total & 299 & 9 & 2.9 \\
\hline
\end{tabular}

Table 2. Relationship of sickling with G-6PD. deficiency.

\begin{tabular}{lccc}
\hline Type & Total No. & $\begin{array}{l}\text { No. of G-6-PD. } \\
\text { deficient }\end{array}$ & Percentage \\
\hline Sickler & 36 & 2 & 5.5 \\
Non- & 263 & 7 & 2.6 \\
sickler & & &
\end{tabular}

Table 3. Relationship of G-6-PD. deficiency with sickling.

\begin{tabular}{lccc}
\hline Type & Total No. & $\begin{array}{l}\text { No. of } \\
\text { sickler }\end{array}$ & Percentage \\
\hline $\begin{array}{l}\text { G-6-PD. } \\
\text { deficient }\end{array}$ & 9 & 2 & 22.3 \\
$\begin{array}{l}\text { Non-G-6-PD. } \\
\text { deficient }\end{array}$ & 290 & 34 & 11.5 \\
\hline
\end{tabular}

Table 4. Amount of haemoglobin in the population and in G-6-PD. deficient cases.

\begin{tabular}{rcr}
\hline $\begin{array}{c}\text { Haemoglobin in } \\
\text { grams }\end{array}$ & $\begin{array}{c}\text { Out of total } \\
\text { (299) }\end{array}$ & $\begin{array}{c}\text { Out of G-6-PD } \\
\text { deficient(9) }\end{array}$ \\
\hline 7.5 to 9.0 & $96(32.1 \%)$ & $3(33.3 \%)$ \\
9.1 to 10.5 & $93(31.1 \%)$ & $4(44.4 \%)$ \\
10.6 to 12.0 & $76(25.4 \%)$ & $1(11.1 \%)$ \\
12.1 to 13.5 & $33(11.0 \%)$ & $1(11.1 \%)$ \\
Above 13.6 & $1(0.33 \%)$ & $0(0.0 \%)$ \\
\hline
\end{tabular}




\section{CONCLUSION}

Out of randomly selected 299 Tibetans, only $9(2.9 \%)$ had G-6-PD. deficiency. It was higher in males than females and in children than in older individuals. But from the studies of GELPI (1965), HuSEYIN (1967) and OwUSU (1973) it is difficult to say whether the incidence varies in different sexes or not.

Sickling and G-6-PD. deficiency abnormalities were recorded, going hand in hand. Higher incidence of G-6-PD. deficiency in sicklers has also been reported by LEwis (1967).

Among the Tibetans, below 12 grams haemoglobin was recorded in $88.6 \%$ whereas with G-6-PD. deficiency in $88.8 \%$. So no significant difference in amount of haemoglobin inbetween normal and G-6-PD. deficient population was recorded.

\section{ACKNOWLEDGEMENTS}

I remain grateful to the representative $\mathrm{H}$. $\mathrm{H}$. Dalai Lama at Chandragiri resettlement Camp, Ganjam, Orissa, for his kind permission and cooperation while collecting data from among the subjects in the field. My thanks are also due to Dr. S. K. NAYAK, M.B.B.S., M. D., at M. K. C. G. Medical College, Berhampur, Ganjam, Orissa, for his technical guidance and encouragements as well.

\section{REFERENCES}

BeUtLer, E., 1957: The glutathione instability of drug sensitive red cell: a new method for the detection of drug sensitivity. J. Lab. Clin.
Med., 49: 84-95.

ChA TTERJEA, J. B., 1966 : Haemoglobinopa thies, glucose-6-phosphate dehydrogenase deficiency and allied problems in the Indian subcontinent. Bull. World Health Organ., 35: 837-856.

Chatterjee, K. D., 1969: Parasitology (7th Edn.)., published by SolankI, B. R., (Mrs.) Kher, M. M., PARANDE, C. M. and JunAKAR, R. D., Amrit Banerjee Road, Calcutta-26.205. GelPi, A.P., 1965: Blood, 25: 486.

Gills, H. M., Fletcher, K.A., Hendrickse, R. G., Lindner, R., Reddy, S. and Allan, N., 1967: Lancet, 1: 138.

Huseyin, Sipahiolu, 1967: Lancet, $2: 51$.

LEWIS, R. A., 1967: Lancet, 1: 825 .

Lewis, R. A. and Hathorn, M., 1965: Correlation of $\mathrm{S}$ haemoglobin with glucose-6-phosphate dehydrogenase deficiency and its significance. Blood, 26 : 176-180.

OWUSU, S. K., 1973: Lancet, 2: 325.

Solanki, B. R., (Mrs.)Kher, M. M., PARANDE, C. M. and JUNAKAR, R. D., 1967: Ind. Med. Gazette, 7: 62 .

SHAKER, Yehia, ONSI, A. and AzIz, R., 1966 : Am. J. Hum. Genet., 18: 609.

Wintrobe, M. M., 1967 : Clinical Haematology (6th Edn.). Lee and Febiger, Philadelphia. 702.

World Health Organisation, 1967 : Standardisation of procedures for the study of glucose-6phosphate dehydrogenase. Tech. Rep. Series, 366.

(Received January 24, 1977) 
オリッサ在住チベット人亡命者におけるブドウ糖-6ーリン酸

脱水素酵素欠乏の頻度及びその他の血液性状との相関

\section{Srisha Patel}

B. J. B. 大学人類学教室, インド

インドのオリッサ州ガンジャム地区のチベット人亡命者 299 名のうち, わずか 9 名(2.9\%)において glucose -6-phosphate dehydrogenase (G-6-PD.) 欠乏がみられた。G-6-PD. 欠乏の頻度は女性より男性で, 成人 より子供で高かったが，他の研究者の結果も参照すると，G-6-PD. 欠乏の頻度に性差があるかどうかは不明 である。

赤血球の鎌状化を示す者の方が，示さない者に比較して G-6-PD. 欠乏の頻度は高かった。 チベット人の $88.6 \%$ はへモグロビン量が $12 \mathrm{~g}$ 以下で, それが G-6-PD. 欠乏者の $88.8 \%$ を占めた。従っ て，正常者之 G-6-PD. 欠乏者の集団間にへモグロビン量の有意な差は観察されなかった。 